NASA/TM-2010-216103

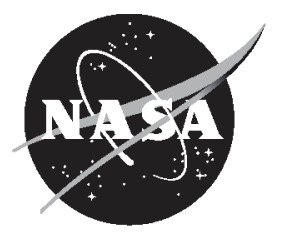

\title{
Probabilistic Simulation for Nanocomposite Fracture
}

Christos C. Chamis

Glenn Research Center, Cleveland, Ohio 


\section{NASA STI Program . . . in Profile}

Since its founding, NASA has been dedicated to the advancement of aeronautics and space science. The NASA Scientific and Technical Information (STI) program plays a key part in helping NASA maintain this important role.

The NASA STI Program operates under the auspices of the Agency Chief Information Officer. It collects, organizes, provides for archiving, and disseminates NASA's STI. The NASA STI program provides access to the NASA Aeronautics and Space Database and its public interface, the NASA Technical Reports Server, thus providing one of the largest collections of aeronautical and space science STI in the world. Results are published in both non-NASA channels and by NASA in the NASA STI Report Series, which includes the following report types:

- TECHNICAL PUBLICATION. Reports of completed research or a major significant phase of research that present the results of NASA programs and include extensive data or theoretical analysis. Includes compilations of significant scientific and technical data and information deemed to be of continuing reference value. NASA counterpart of peer-reviewed formal professional papers but has less stringent limitations on manuscript length and extent of graphic presentations.

- TECHNICAL MEMORANDUM. Scientific and technical findings that are preliminary or of specialized interest, e.g., quick release reports, working papers, and bibliographies that contain minimal annotation. Does not contain extensive analysis.

- CONTRACTOR REPORT. Scientific and technical findings by NASA-sponsored contractors and grantees.
- CONFERENCE PUBLICATION. Collected papers from scientific and technical conferences, symposia, seminars, or other meetings sponsored or cosponsored by NASA.

- SPECIAL PUBLICATION. Scientific, technical, or historical information from NASA programs, projects, and missions, often concerned with subjects having substantial public interest.

- TECHNICAL TRANSLATION. Englishlanguage translations of foreign scientific and technical material pertinent to NASA's mission.

Specialized services also include creating custom thesauri, building customized databases, organizing and publishing research results.

For more information about the NASA STI program, see the following:

- Access the NASA STI program home page at http://www.sti.nasa.gov

- E-mail your question via the Internet to help@ sti.nasa.gov

- Fax your question to the NASA STI Help Desk at $443-757-5803$

- Telephone the NASA STI Help Desk at 443-757-5802

- Write to: NASA Center for AeroSpace Information (CASI) 7115 Standard Drive Hanover, MD 21076-1320 
NASA/TM-2010-216103

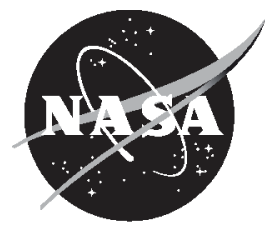

\section{Probabilistic Simulation for Nanocomposite Fracture}

Christos C. Chamis

Glenn Research Center, Cleveland, Ohio

National Aeronautics and

Space Administration

Glenn Research Center Cleveland, Ohio 44135 
This report is a formal draft or working paper, intended to solicit comments and ideas from a technical peer group.

This report contains preliminary findings, subject to revision as analysis proceeds.

Trade names and trademarks are used in this report for identification only. Their usage does not constitute an official endorsement, either expressed or implied, by the National Aeronautics and Space Administration.

Level of Review: This material has been technically reviewed by technical management.

Available from

NASA Center for Aerospace Information 7115 Standard Drive

Hanover, MD 21076-1320
National Technical Information Service 5285 Port Royal Road Springfield, VA 22161

Available electronically at http://gltrs.grc.nasa.gov 


\title{
Probabilistic Simulation for Nanocomposite Fracture
}

\author{
Christos C. Chamis \\ National Aeronautics and Space Administration \\ Glenn Research Center \\ Cleveland, Ohio 44135
}

\begin{abstract}
A unique probabilistic theory is described to predict the uniaxial strengths and fracture properties of nanocomposites. The simulation is based on composite micromechanics with progressive substructuring down to a nanoscale slice of a nanofiber where all the governing equations are formulated. These equations have been programmed in a computer code. That computer code is used to simulate uniaxial strengths and fracture of a nanofiber laminate. The results are presented graphically and discussed with respect to their practical significance. These results show smooth distributions from low probability to high.
\end{abstract}

\section{Introduction}

The research in the nanoscale technology has exploded over the recent past. An indication of this explosion is that the Society of Aerospace Material and Processing Engineers (SAMPE) Conference is devoting four sessions of about six papers each in the last 5 years. These papers cover practically all current research activities. The majority of the research is devoted to processing because of the difficulties involved in making a useful material (Ref. 1). A few investigators have been fortunate to make some testing samples, which they subsequently tested to obtain limited data (Ref. 2). A few other investigators researched the characterization of fatigue (Ref. 3) and creep (Ref. 4). A couple of papers explored the construction of nanocomposites for rocket ablative material (Ref. 5) and for carbon nanotubes for adaptive structures (Ref. 6). One paper ventured to describe a computer simulation of macroscopic properties of carbon nanotubes polymer composites (Ref. 7). However, there are no results of what special macroscopic properties are included. Reference 7 shows one stress strain curve and citation of several references. One recent article (Ref. 8) describes multiscale modeling and simulation of nanostructural materials from atomistic to micromechanics. This article does not include information on nanocomposites, but it mentions that mechanistic models will be needed in the end. It is becoming abundantly clear that no holistic approach has been used to investigate the mechanistic prediction of uniaxial strength and fracture.

In this paper a unique mechanistic method is described to probabilistically simulate five uniaxial strengths and fracture of a nanofiber uniaxial composite. The mechanistic deterministic simulation of all uniaxial properties is described in a previous paper (Ref. 9).

\section{Fundamentals}

The fiber alignment with uniform dispersion is not met in nanocomposites. It is assumed herein that the fibers are aligned only for predicting "point" through-the-thickness properties. The fussiness can be simulated by estimating the angle of single fibers through the thickness. Therefore, it is assumed that an aligned unidirectional typical section of a nanocomposite is as illustrated schematically in Figure 1 on the left 1(a). A nanoply is schematically shown in Figure 1 on the right $1(\mathrm{~b})$. The input includes the constituent material properties, Tables 1 and 2, the fabrication parameters, environmental, and the loading conditions. 
TABLE 1.-T300 GRAPHITE NANOFIBER (PYROGRAF II) PROPERTIES

[Conversion factors: $110 \mathrm{~nm}=2.756 \times 10^{-6} \mathrm{in}$; $\mathrm{psi}=6.89 \mathrm{~Pa} ; \mathrm{lb} / \mathrm{in}^{3}=1146 \mathrm{~kg} / \mathrm{cm}^{3} ;$ in. $/ \mathrm{in} .{ }^{\circ} \mathrm{F}=(2 / 5) ; \mathrm{cm} / \mathrm{cm} /{ }^{\circ} \mathrm{F} ; \mathrm{Btu}=1055 \mathrm{joules}$.]

Number of fibers per end

Filament equivalent diameter

Weight density

Normal moduli (11)

Normal moduli (22)

Poisson's ratio (12)

Poisson's ratio (23)

Shear moduli (12)

Shear moduli (23)

Thermal expansion coefficient (11)

Thermal expansion coefficient (22)

Heat conductivity (11)

Heat conductivity (22)

Heat capacity

Dielectric strength (11)

Dielectric strength (22)

Dielectric constant (11)

Dielectric constant (22)

Capacitance

Resistivity

Tensile strength

Compressive strength

Shear strength

Normal damping capacity (11)

Normal damping capacity (22)

Shear damping capacity (12)

Shear damping capacity (23)

Melting temperature

\begin{tabular}{|c|c|c|}
\hline Symbol & Value & Units \\
\hline $\mathrm{Nf}$ & 1.0 & number \\
\hline $\mathrm{df}$ & $2.756 \times 10^{-6}$ & in. \\
\hline Rhof & 0.064 & $\mathrm{lb} /$ in. $* * 3$ \\
\hline Ef11 & $1.0 \times 10^{9}$ & psi \\
\hline Ef22 & $7.0 \times 10^{7}$ & psi \\
\hline Nuf12 & 0.2 & Nondimensional \\
\hline Nuf23 & 0.25 & Nondimensional \\
\hline Gf12 & $5.0 \times 10^{7}$ & psi \\
\hline Gf23 & $3.5 \times 10^{7}$ & psi \\
\hline Alfaf1 1 & $-5.5 \times 10^{-7}$ & in. $/$ in $/{ }^{\circ} \mathrm{F}$ \\
\hline Alfaf 22 & $5.6 \times 10^{-6}$ & in./in. $/{ }^{\circ} \mathrm{F}$ \\
\hline Kf11 & 444.0 & $\mathrm{Btu} / \mathrm{hr} / \mathrm{ft}^{2} /{ }^{\circ} \mathrm{F} / \mathrm{in}$. \\
\hline Kf22 & 4.0 & $\mathrm{Btu} / \mathrm{hr} / \mathrm{ft}^{2} /{ }^{\circ} \mathrm{F} / \mathrm{in}$. \\
\hline $\mathrm{Cf}$ & 0.22 & $\mathrm{Btu} / \mathrm{lb} /{ }^{\circ} \mathrm{F}$ \\
\hline $\mathrm{KeF} 11$ & 0.0 & V/in. \\
\hline $\operatorname{Kef} 22$ & 0.0 & V/in. \\
\hline Gamma11 & 0.0 & in. $/ V$ \\
\hline Jamma22 & 0.0 & in. $/ \mathrm{V}$ \\
\hline Cef & 0.0 & V \\
\hline Ref & 0.0 & $\Omega$-in. \\
\hline SfT & $8.0 \times 10^{5}$ & psi \\
\hline $\mathrm{SiC}$ & $6.0 \times 10^{5}$ & psi \\
\hline SfS & $4.0 \times 10^{5}$ & psi \\
\hline psi11f & 0.38 & $\%$ Energy \\
\hline psi22f & 6.3 & $\%$ Energy \\
\hline psi12f & 3.34 & $\%$ Energy \\
\hline psi23f & 6.3 & \%Energy \\
\hline TMf & 6000.0 & ${ }^{\circ} \mathrm{F}$ \\
\hline
\end{tabular}

TABLE 2.-INTERMEDIATE MODULUS HIGH-STRENGTH MATRIX (EPOXY)

[Conversion factors: $110 \mathrm{~nm}=2.756 \times 10^{-6} \mathrm{in} . ; \mathrm{psi}=6.89 \mathrm{~Pa} ; \mathrm{lb} / \mathrm{in}^{3}=1146 \mathrm{~kg} / \mathrm{cm}^{3} ; \mathrm{in} . / \mathrm{in} . /{ }^{\circ} \mathrm{F}=(2 / 5) ; \mathrm{cm} / \mathrm{cm} /{ }^{\circ} \mathrm{C} ; \mathrm{Btu}=1055$ joules]

\begin{tabular}{|c|c|c|c|}
\hline Description & Symbol & Value & Units \\
\hline Weight density & Rhom & 0.044 & lb/in.**3 \\
\hline Normal modulus & Em & 500000.0 & psi \\
\hline Poisson's ratio & Num & 0.35 & Nondimensional \\
\hline Thermal expansion coefficient & Alfa m & $3.6 \times 10^{-5}$ & in. $/$ in. $/{ }^{\circ} \mathrm{F}$ \\
\hline Heat conductivity & $\mathrm{Km}$ & 0.008681 & $\mathrm{Btu} / \mathrm{hr} / \mathrm{ft}^{2} /{ }^{\circ} \mathrm{F} / \mathrm{in}$. \\
\hline Heat capacity & $\mathrm{Cm}$ & 0.25 & $\mathrm{Btu} / \mathrm{lb} /{ }^{\circ} \mathrm{F}$ \\
\hline Dielectric strength & Kem & 0.0 & V/in. \\
\hline Dielectric constant & Gammam & 0.0 & in./V \\
\hline Capacitance & Cem & 0.0 & V \\
\hline Resistivity & Rem & 0.0 & $\Omega$-in. \\
\hline Moisture expansion coefficient & Betam & 0.0033 & in./in./\%moisture \\
\hline Diffusivity & Dm & $2.16 \times 10^{-7}$ & in. $* * 2 / \mathrm{hr}$ \\
\hline Saturation & $\mathrm{Mm}$ & 0.0 & \%moisture \\
\hline Tensile strength & SmT & 15000.0 & psi \\
\hline Compressive strength & $\mathrm{SmC}$ & 35000.0 & psi \\
\hline Shear strength & $\mathrm{SmS}$ & 13000.0 & psi \\
\hline Allowable tensile strain & eps mT & 0.02 & in./in. \\
\hline Allowable compression strain & eps $\mathrm{mC}$ & 0.05 & in./in. \\
\hline Allowable shear strain & eps mS & 0.035 & in./in. \\
\hline Allowable torsional strain & eps mTOR & 0.035 & in./in. \\
\hline Normal damping capacity & psiNM & 6.6 & \%energy \\
\hline Shear damping capacity & psiSm & 6.9 & \%energy \\
\hline Void heat conductivity & Kv & 0.0012 & Btu/hr/in. $/{ }^{\circ} \mathrm{F}$ \\
\hline Glass transition temperature & Tgdr & 420.0 & ${ }^{\circ} \mathrm{F}$ \\
\hline Melting temperature & $\mathrm{TMm}$ & 0.0 & ${ }^{\circ} \mathrm{F}$ \\
\hline
\end{tabular}




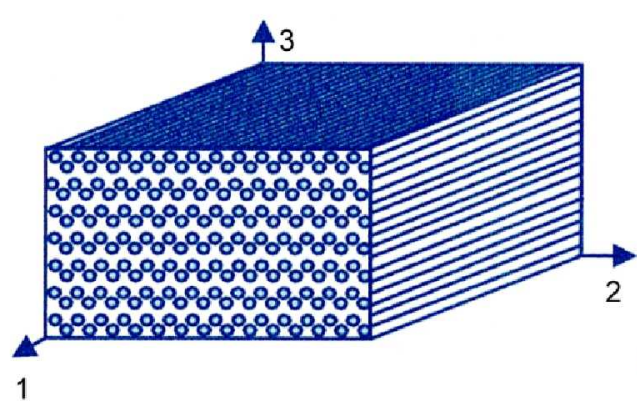

(a)

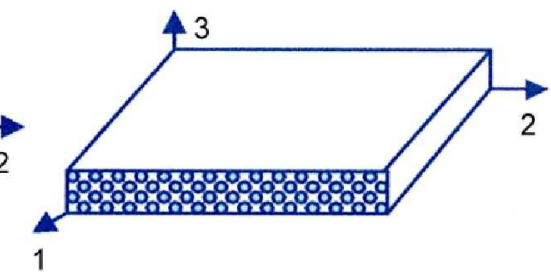

(b)

Figure 1.—Unidirectional nanocomposite typical section. (a) Nanocomposite.

(b) Nanoply.

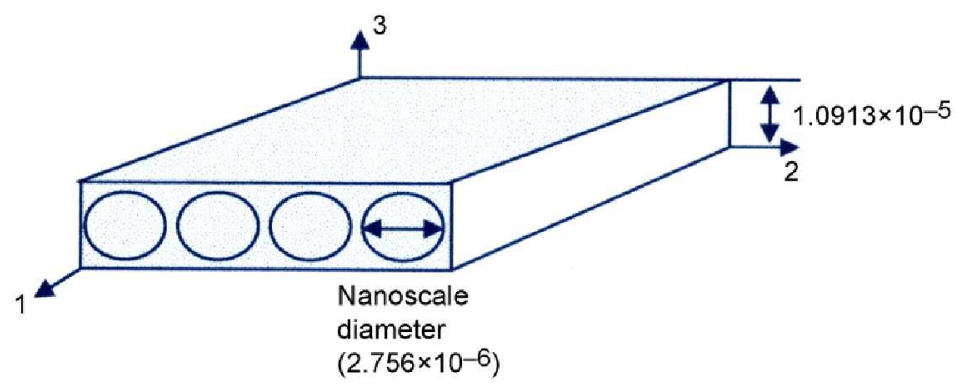

Figure 2.-Nanoscale isolation of a typical part (units are in in.).

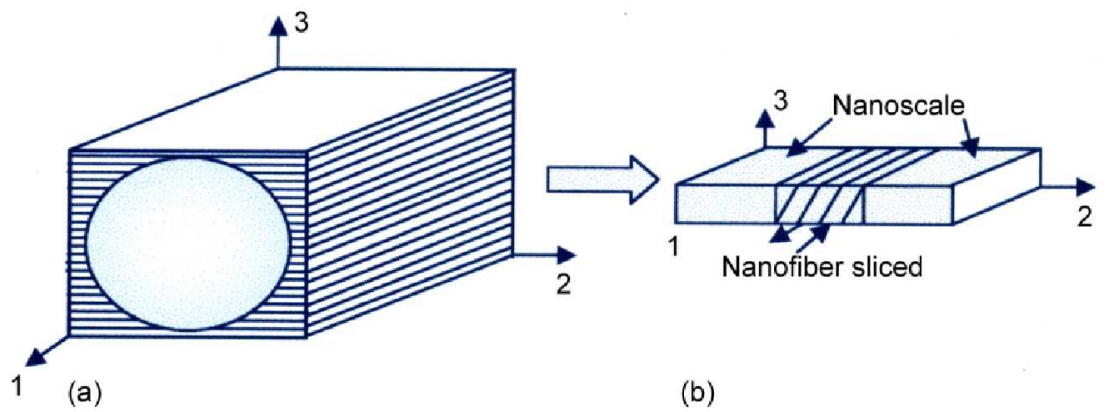

Figure 3.-Nanofiber substructuring. (a) Several slices through the thickness. (b) Nanofiber sliced.

The strength prediction is expedited by the following geometric diagrams: An exploded view of nanoscale isolation of a typical part is shown in Figure 2 with nanoscale dimensions. A single nanofiber schematic with substructuring is shown in Figure 3(a), and a typical subslice is shown in Figure 3(b).

A nanosubply with its corresponding stresses is shown in Figure 4. The nanomechanics predictive equations are derived by using Figure 4 . The equations used are all programmed in ICAN/JAVA (Ref. 10).

Prior to describing the results obtained, it is instructive to describe the interphase and how it is modeled. The schematics in Figure 5 show a vertical section, upper figure part, with unit thickness of the nanocomposite and a single fiber in it. As can be seen in the slice, lower figure, the fiber interphase is represented by a series of progressively larger volume voids starting with the smallest near the matrix interface and ending with the largest in the fiber interface. It can be visualized that the stress in the matrix will be magnified because of the voids. This magnification is shown in Figure 6 for a specific nanocomposite with 0.05 fiber volume ratio and with void volume ratio varying from 0.05 to 0.4 . The 
interesting point to note in the lower part of Figure 5 is that the matrix is continuous even though it is filled with progressively larger nano voids; otherwise the stresses will not be continuous in the matrix. It is instructive to elaborate a bit further with the geometry of Figure 5, lower part. In order to fill up a conventional ply of 0.005 in. thick and a width of 1 in., it will require about $1 \times 10^{6}$ nanofibers, a very large number indeed. The magnification factor of the voids effect in the interphase is show in Figure 6 . As can be seen in Figure 6, the magnification factor increases from a value of about 1.1 to a maximum of about 2. Therefore, the maximum void effect will be nearest to the fiber interface. The author is not aware of any experimental data that shows these effects. It is important to note that this is the only mechanics approach to the interphase description.

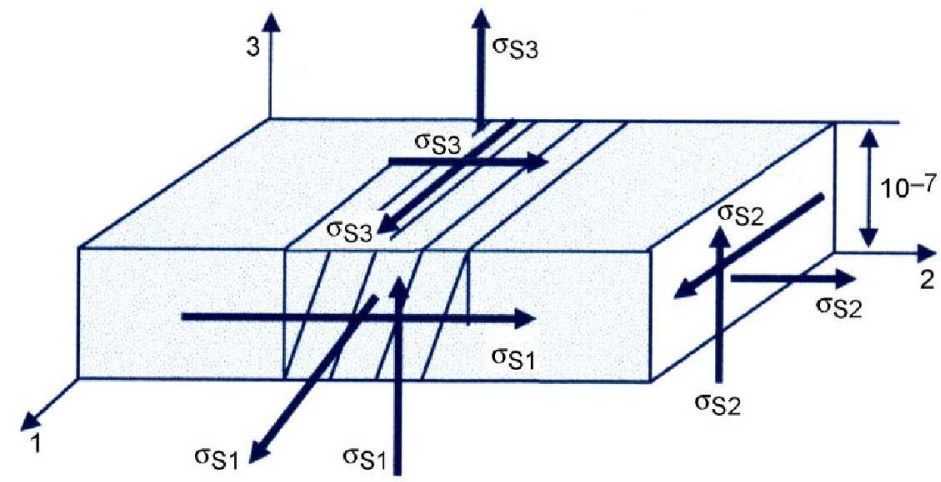

Figure 4.-Nanostresses on a nanosubply (units are in in.).

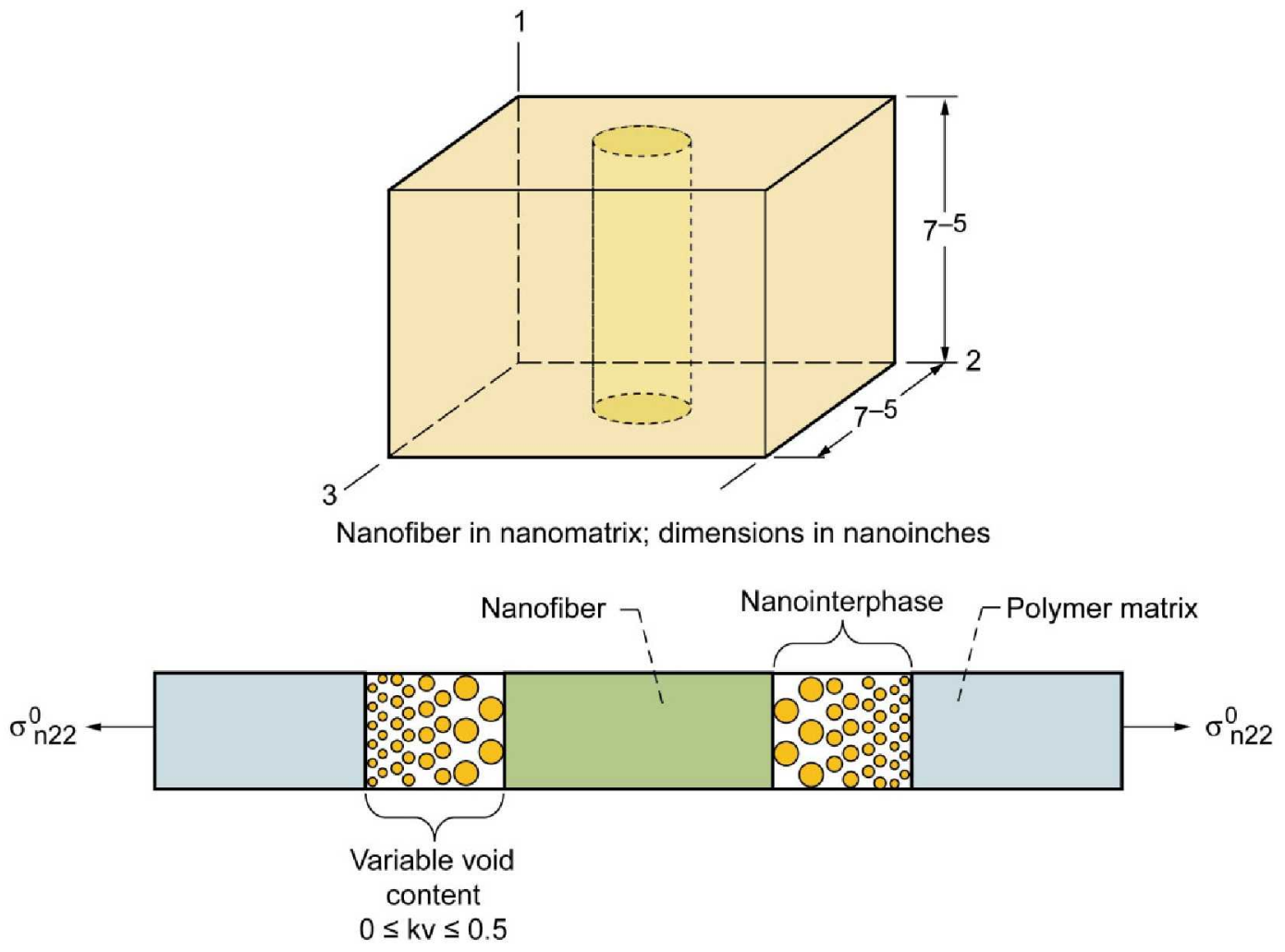

Figure 5.-Vertical section of a composite nanocell through nanofiber center. 


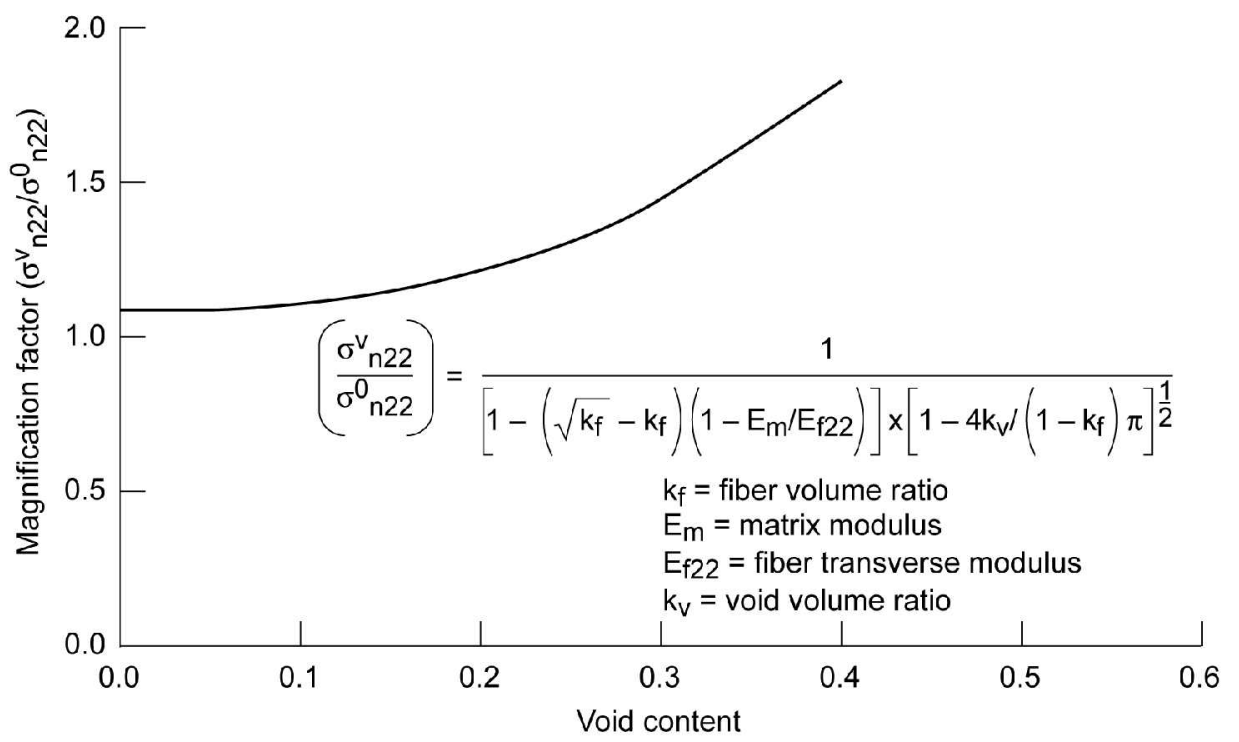

Figure 6.-Nanocomposite magnification factor.

\section{Results and Discussion}

In this section the probabilistic results are presented and discussed starting with the large voids in the interphase. The probabilistic void magnification factor is shown graphically in Figure 7 . It can be seen in Figure 7 that the larger the void content the greater the deviation. The left most figure is closest to the matrix interphase fiber interface while the right most curve is closest to the interphase interface. The respective scatter is about 0.1 for the curve closest to the matrix to about 1 for the curve closest to the fiber. The corresponding sensitivities are shown in Figure 8. It can be seen in this figure that the void sensitivities on the magnification factor is large. The probabilistic void effects on the uniaxial strengths are plotted in Figure 9. Figure 9(a) shows the spread in the longitudinal tensile strength; Figure 9(b), in the longitudinal compressive strength; Figure 9(c), in the transverse tensile strength and Figure $9(\mathrm{~d})$ in the transverse compressive strength. It can be seen in Figure 9 that the distribution for the two longitudinal strengths is relatively large. It is from 150 to $650 \mathrm{ksi}$, for tensile strength and with a distribution of about $500 \mathrm{ksi}$, and for the compressive strength is from 140 to $500 \mathrm{ksi}$ or a distribution of about $360 \mathrm{ksi}$. The corresponding probabilistic sensitivities are plotted in Figure 10 for tensile and Figure 11 for compressive. It can be seen in these two figures that there is no difference in the sensitivities for the three probabilities. The probabilistic intralaminar shear strength is plotted in Figure 12. The distribution in this strength is from about 6,000 to $\sim 16,000 \mathrm{psi}$ or $\sim 10 \mathrm{ksi}$ spread. It is a relatively wide distribution from lowest probability to the highest. The corresponding probability sensitivities are plotted in Figure 13 for uniaxial nano transverse tensile strength. Note that these probabilistics are for $0.0001,0.50$, and 0.9999 . They are about the same and may be easily interchangeable as well as for three fiber volume ratios.

The respective sensitivities for the other nanouniaxial strengths are the same and are not shown. The fracture for uniaxial nanofiber composites are the same as their respective uniaxial nanofiber uniaxial strengths. 


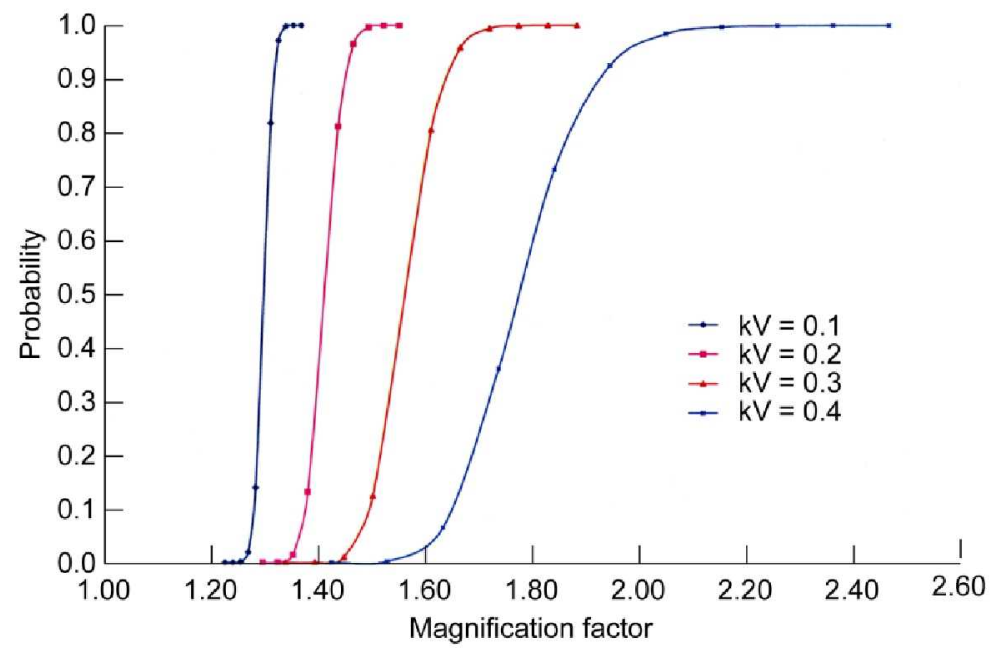

Figure 7.-Probabilistic magnification factor of voids in the interphase.

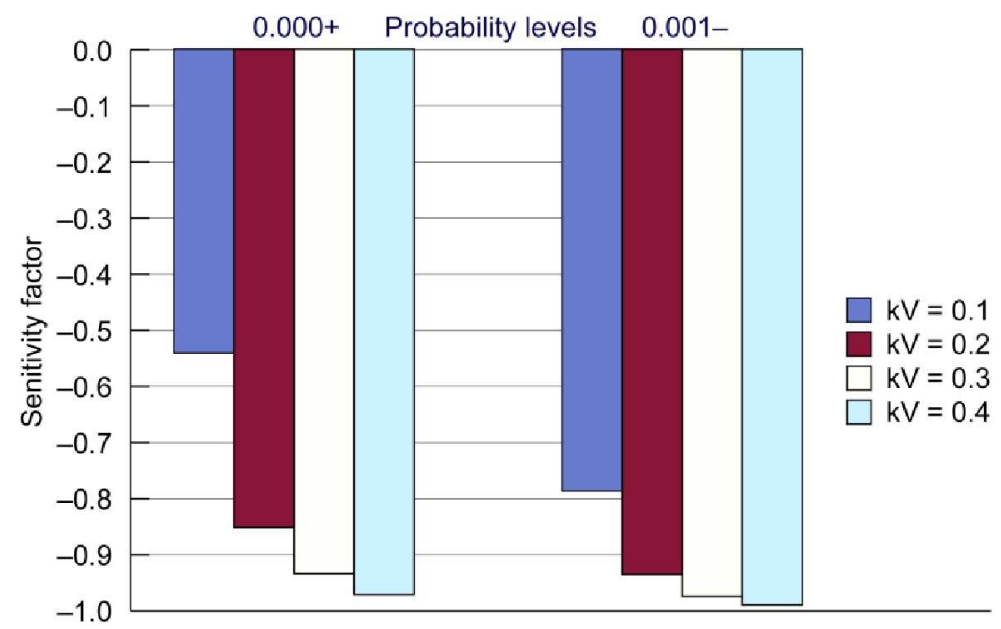

Figure 8.-Voids sensitivities on the interphase magnification factor. 

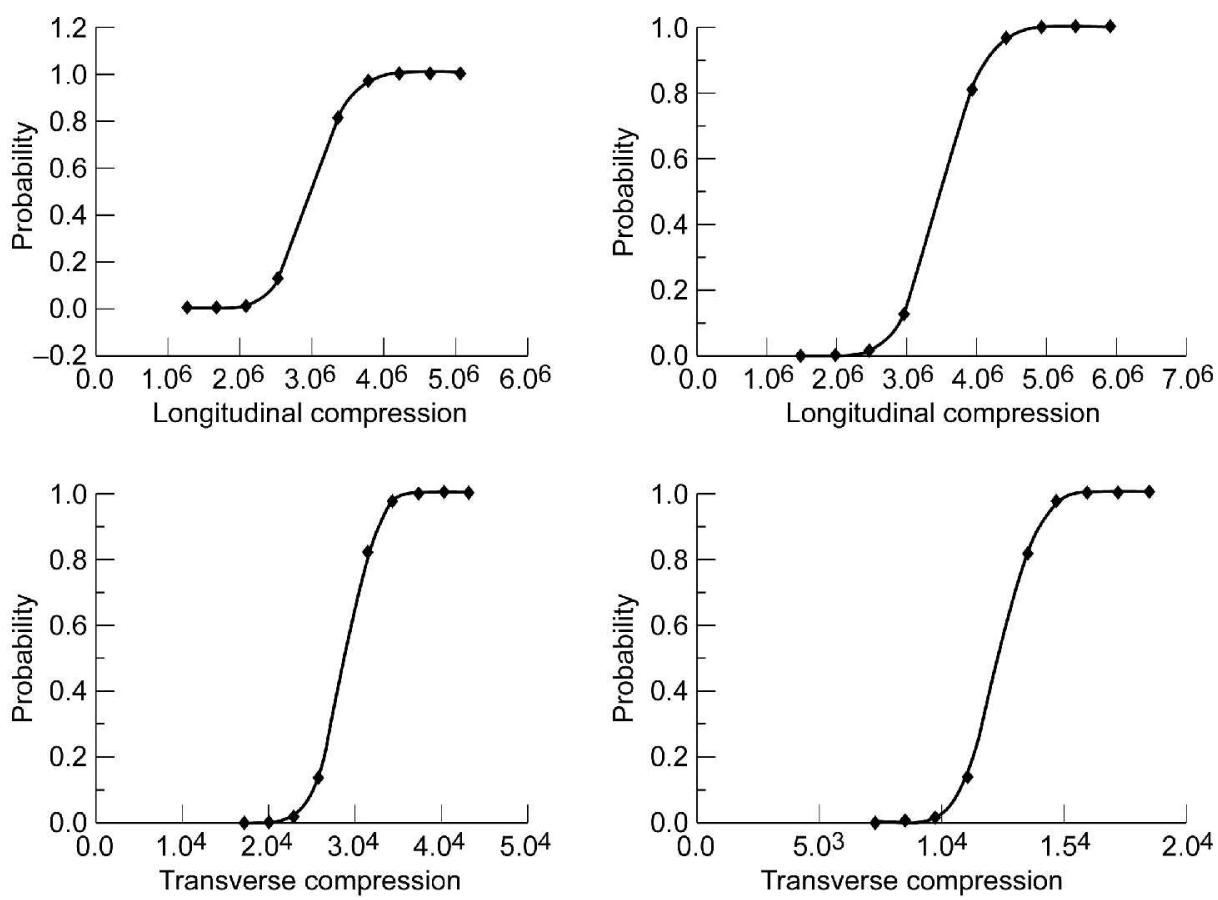

Figure 9.-Probabilistically plotted nanouniaxial strengths.

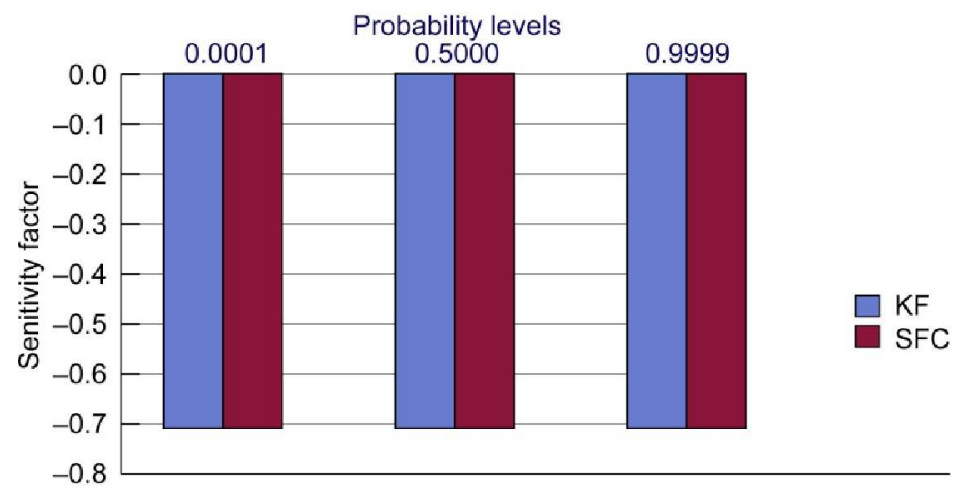

Figure 10.-Probabilistic sensitivities for nano longitudinal uniaxial strength.

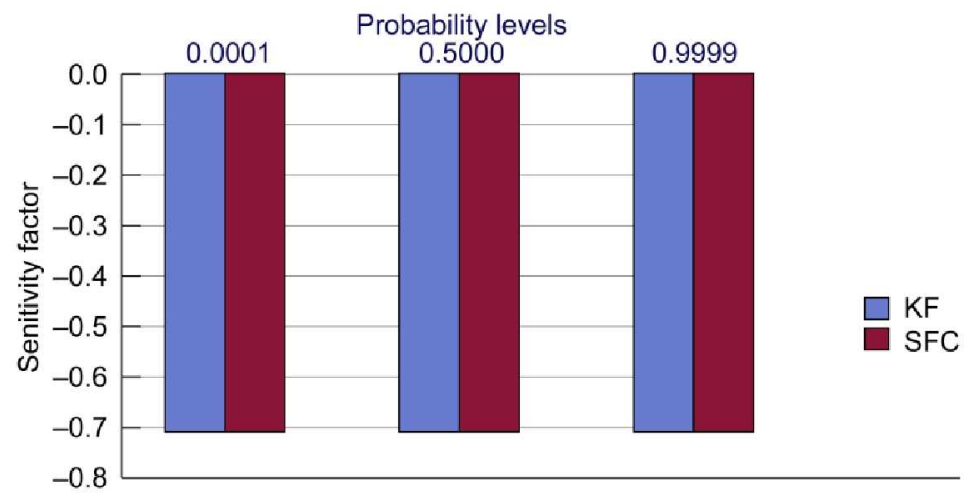

Figure 11.-Probabilistic sensitivities for the nanocompressive uniaxial strength. 


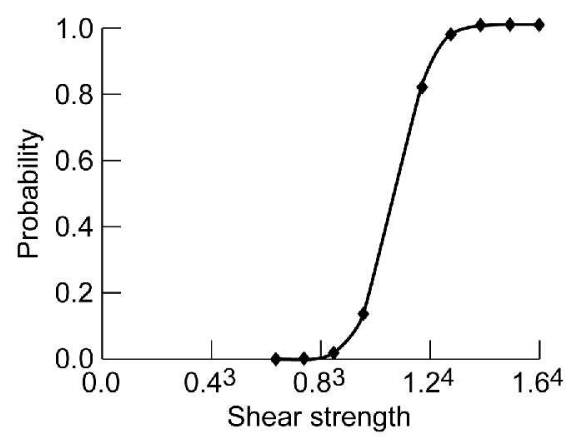

Figure 12.-Probabilistically plotted intralaminar uniaxial shear strength.
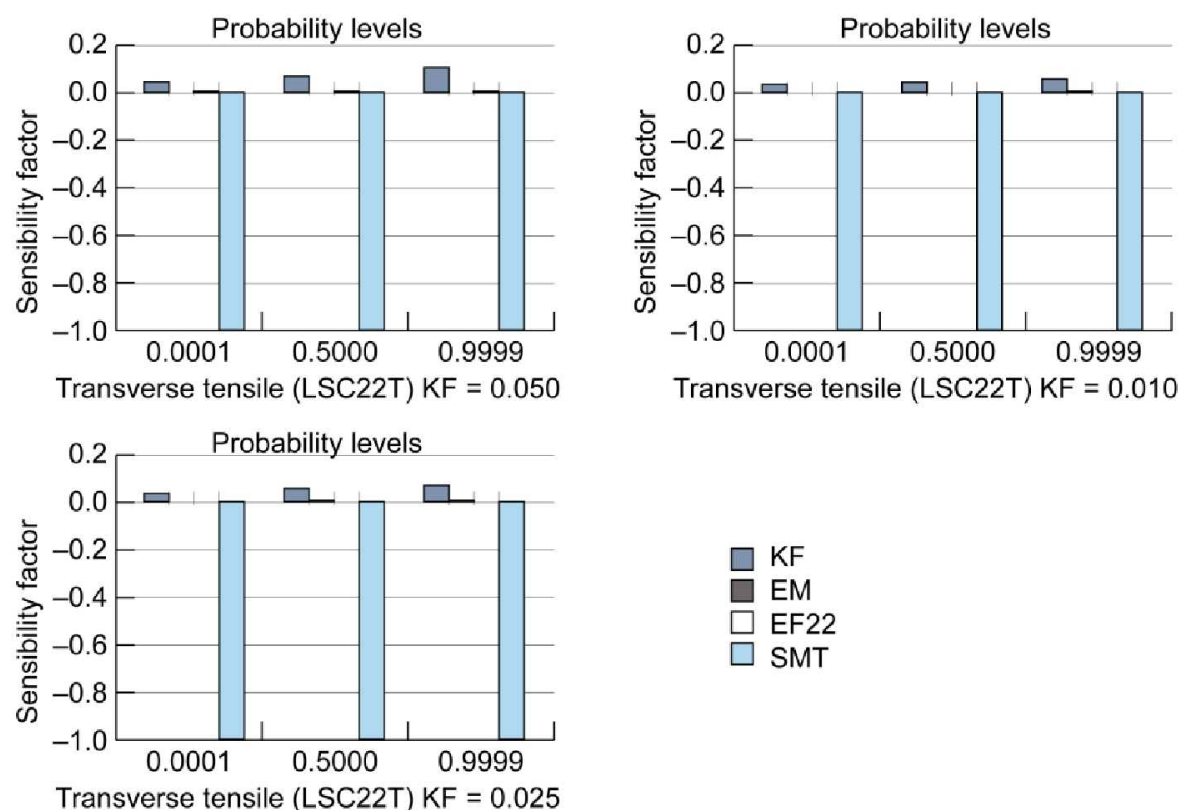

Figure 13.-Probabilistic sensitivities for nanouniaxial transverse tensile strength for three different probabilities.

\subsection{Concluding Remarks}

The salient remarks from an investigation to characterize an aligned monofiber nanolaminate are as follows:

(1) The characterization for the nanolaminate (composite) was based on a series of progressive substructuring down a sliced single-nano diameter fiber.

(2) The theoretical development and all the equations are included in a computer code called ICAN/JAVA.

(3) The uniaxial strength and fracture includes two fabrication parameters, 5-nano-uniaxial strengths/fracture.

(4) The nanolaminate investigated consists of single nanofiber laminate with 0.05 fiber volume ratio.

(5) The effects of the interphase are especially important and are represented by progressively large amounts of nano voids from the matrix interface to the fiber interphase. 
(6) The probabilistic evaluation characterizes the effects of uncertainties in all participating variables.

(7) The voids uncertainties indicate as the void volume ratio increases the distribution increases as well.

(8) The voids contribute significantly to matrix dominated strengths/fracture. That is, longitudinal compression, transverse tension and compression, and all intralaminar/interlaminar properties.

\section{References}

1. M. Jose, J. Tyner, E. Nyairo, D. Dean, Synthesis and processing of aligned carbon nanotube based fibers, 49th Int SAMPE Symp and Exhib Conf Proc, 2004.

2. G. Ayalasomayajuala, A. Garg, S. Kapila, K. Chandrashekhara, V. Flanigan, Fabrication and evaluation of rice hull derived nano silica composites, SAMPE, 49th Int Symp and Exhib Conf Proc, 2004.

3. T. Karaki, J.P. Killgore, J.C. Seferis, Characterization of fatigue behavior of polynanomeric matrix composites, SAMPE, 49th Int Symp and Exhib Conf Proc, 2004.

4. A. Ranade, N.A. D'Souza, K. Nayak, B. Gnade, D. Fairbrother, Correlation between creep-recovery, crystallization and dispersion of linear low density polyethylene nanocomposite films, SAMPE, 48th Int Symp and Exhib Conf Proc, 48, 1, $2164-2176,2003$.

5. J.H. Koo, H. Stretz, J. Weispfenning, Z.P. Luo, W. Wootan, Nanocomposite rocket ablative materials: Subscale ablation test, 49th Int SAMPE Symp and Exhib Conf Proc, 2004.

6. S. Muhle, H.P. Monner, P. Wiersch, P., Carbon-nanotubes for adaptive structures, SAMPE, 48th Int Symp and Exhib, 48, 1, 1181-1190, 2003.

7. D. Srivastava, C. Wei, Computer simulations of macroscopic properties of carbon-nanotube polymer composites, SAMPE, 48th Int Symp and Exhib, 48, 1, 2153-2163, 2003.

8. T.S. Gates et al., Computational materials: Multi-scale modeling and simulation of nanostructural materials. Comp Sci T, 65 (2005), 2416-2434.

9. C.C. Chamis, Composite nanomechanics properties prediction, NASA/TM-2007-214673.

10. L.M. Handler, C.C. Chamis, ICAN/JAVA computer code. 


\begin{tabular}{|c|c|c|}
\hline \multicolumn{2}{|c|}{ REPORT DOCUMENTATION PAGE } & $\begin{array}{l}\text { Form Approved } \\
\text { OMB No. 0704-0188 }\end{array}$ \\
\hline \multicolumn{3}{|c|}{$\begin{array}{l}\text { The public reporting burden for this collection of information is estimated to average } 1 \text { hour per response, including the time for reviewing instructions, searching existing data sources, gathering and maintaining the } \\
\text { data needed, and completing and reviewing the collection of information. Send comments regarding this burden estimate or any other aspect of this collection of information, including suggestions for reducing this } \\
\text { burden, to Department of Defense, Washington Headquarters Services, Directorate for Information Operations and Reports (0704-0188), 1215 Jefferson Davis Highway, Suite } 1204 \text {, Arlington, VA 22202-4302. } \\
\text { Respondents should be aware that notwithstanding any other provision of law, no person shall be subject to any penalty for failing to comply with a collection of information if it does not display a currently valid OMB } \\
\text { control number. } \\
\text { PLFASE DO NOT RETURN YOUR FORM TO THE ABOVE ADDRESS. }\end{array}$} \\
\hline $\begin{array}{l}\text { 1. REPORT DATE (DD-MM-YYYY) } \\
01-03-2010\end{array}$ & $\begin{array}{l}\text { 2. REPORT TYPE } \\
\text { Technical Memorandum }\end{array}$ & 3. DATES COVERED (From - To) \\
\hline \multirow{3}{*}{\multicolumn{2}{|c|}{$\begin{array}{l}\text { 4. TITLE AND SUBTITLE } \\
\text { Probabilistic Simulation for Nanocomposite Fracture }\end{array}$}} & 5a. CONTRACT NUMBER \\
\hline & & 5b. GRANT NUMBER \\
\hline & & 5c. PROGRAM ELEMENT NUMBER \\
\hline \multirow{3}{*}{\multicolumn{2}{|c|}{$\begin{array}{l}\text { 6. AUTHOR(S) } \\
\text { Chamis, Christos, C. }\end{array}$}} & 5d. PROJECT NUMBER \\
\hline & & 5e. TASK NUMBER \\
\hline & & $\begin{array}{l}\text { 5f. WORK UNIT NUMBER } \\
\text { WBS 432938.11.01.03.02.03.01 }\end{array}$ \\
\hline \multicolumn{2}{|c|}{$\begin{array}{l}\text { 7. PERFORMING ORGANIZATION NAME(S) AND ADDRESS(ES) } \\
\text { National Aeronautics and Space Administration } \\
\text { John H. Glenn Research Center at Lewis Field } \\
\text { Cleveland, Ohio } 44135-3191\end{array}$} & $\begin{array}{l}\text { 8. PERFORMING ORGANIZATION } \\
\text { REPORT NUMBER } \\
\text { E-16748 }\end{array}$ \\
\hline \multirow{2}{*}{\multicolumn{2}{|c|}{$\begin{array}{l}\text { 9. SPONSORING/MONITORING AGENCY NAME(S) AND ADDRESS(ES) } \\
\text { National Aeronautics and Space Administration } \\
\text { Washington, DC 20546-0001 }\end{array}$}} & $\begin{array}{l}\text { 10. SPONSORING/MONITOR'S } \\
\text { ACRONYM(S) } \\
\text { NASA }\end{array}$ \\
\hline & & $\begin{array}{l}\text { 11. SPONSORING/MONITORING } \\
\text { REPORT NUMBER } \\
\text { NASA/TM-2010-216103 }\end{array}$ \\
\hline \multicolumn{3}{|c|}{$\begin{array}{l}\text { 12. DISTRIBUTION/AVAILABILITY STATEMENT } \\
\text { Unclassified-Unlimited } \\
\text { Subject Categories: } 24,61 \text {, and } 65 \\
\text { Available electronically at http://gltrs.grc.nasa.gov } \\
\text { This publication is available from the NASA Center for AeroSpace Information, 443-757-5802 }\end{array}$} \\
\hline
\end{tabular}

\section{SUPPLEMENTARY NOTES}

\section{ABSTRACT}

A unique probabilistic theory is described to predict the uniaxial strengths and fracture properties of nanocomposites. The simulation is based on composite micromechanics with progressive substructuring down to a nanoscale slice of a nanofiber where all the governing equations are formulated. These equations have been programmed in a computer code. That computer code is used to simulate uniaxial strengths and fracture of a nanofiber laminate. The results are presented graphically and discussed with respect to their practical significance. These results show smooth distributions from low probability to high.

15. SUBJECT TERMS

Fiber composites; Multifactor model; Fast probability integrator; Constituent materials

\begin{tabular}{|c|c|c|c|c|c|}
\hline \multicolumn{3}{|c|}{ 16. SECURITY CLASSIFICATION OF: } & \multirow{2}{*}{$\begin{array}{l}\text { 17. LIMITATION OF } \\
\text { ABSTRACT } \\
\text { UU }\end{array}$} & \multirow{2}{*}{$\begin{array}{l}\text { 18. NUMBER } \\
\text { OF } \\
\text { PAGES } \\
15\end{array}$} & \multirow{2}{*}{$\begin{array}{l}\text { 19a. NAME OF RESPONSIBLE PERSON } \\
\text { STI Help Desk (email:help@sti.nasa.gov) } \\
\text { 19b. TELEPHONE NUMBER (include area code) } \\
\text { 443-757-5802 }\end{array}$} \\
\hline $\begin{array}{l}\text { a. REPORT } \\
\text { U }\end{array}$ & $\begin{array}{l}\text { b. ABSTRACT } \\
\text { U }\end{array}$ & $\begin{array}{l}\text { c. THIS } \\
\text { PAGE } \\
\text { U }\end{array}$ & & & \\
\hline
\end{tabular}



